\title{
World Refugee Survey - 1983
}

For 25 years, World Refugee Survey has been published by the U.S. Committee for Refugees. In 1982, The U.S. Committee merged with the American Council of National Services, but retained its name. Readers should not be misled by the title. The publication is a review of the refugee situation largely from the American perspective. Most of the authors are American and most of the articles are American-oriented. Further, though the Survey, particularly its section on Country Reports, is often used as a reference, the quality of World Refugee Survey is uneven.

Between Roger Winter's opening summary of 1982 as a year in which protection for refugees declined, and the statistical section at the end, twelve articles are included. Two deal with general issues: (i.e. the problem of definition and repatriation, primarily in Africa). Three articles take up the case of a specific group of refugees - the Banyarwanda in Uganda and Rwanda - and two other groups which have a special interest for Americans - Palestinians and Soviet Jews.

Two articles take a non-American perspective, one on Australian policy and the other on the role of the InterGovernmental Committee for Migration. Five articles deal directly with U.S. policy: Robert DeVecchi on the U.S. Status determination process; Sid Mohn on U.S. policy towards Central American refugees; Rep. Hamilton Fish on "A Congressional Perspective on Refugee Policy"; and two articles on the adjustment of the Indochinese refugees in the U.S.

Using the measuring stick of refugee protection, Roger Winter (a director of the U.S Committee for Refugees) argues that the situation of refugees has declined. He cites the forcible refoulement of refugees from Djibouti, Thailand, Uganda and the U.S.A., the use of humane deterrence by Hong Kong and the U.S.A., and the lack of protection of Palestinian refugees in Lebanon, of Guatemalans in Mexico and of Vietnamese in the waters of Thailand. His separate article on the Banyarwanda is a valuable, detailed description of the
Ugandan government's orchestrated displacement of 75,000 Banyarwanda in Uganda, both citizens and non-citizens, in October of 1982, 40,000 of whom crossed the border into Rwanda.

Gilbert Jaeger, a former UNHCR official for 27 years, reviews the limitations of the UN definition of a refugee. Unfortunately, his assertion that the alien status is undisputed in defining a refugee is incorrect in both the use of the term refugee and in the review of arguments about definition. The restriction of the UNHCR definition to refugees outside their homeland is indeed a matter of dispute. In the same World Refugeee Survey, for example, the article by Roger Winter quotes refugee experts in Africa who refer to the forcibly displaced Banyarwanda within Uganda as refugees. And in my article on the Palestinians as well as in the general literature, the Arab Palestinians displaced in 1948 from one part of their homeland to another are referred to as refugees.

As Jaeger correctly asserts, it is not theory but practice that restricts the application of the term (as in the case, for example, of the U.S. interdiction of Haitians at sea and, after summary consideration of their claims, sending them back). Similarly, the regular use of humane deterrents, such as the detention of refugee claimants, not only runs counter to the spirit of international refugee law but is explicitly prohibited by Article 31 of the Convention.

Jaeger is very helpful and very clear in considering the issue of economic oppression and deprivation. It is applicable to the consideration of refugee status when economic hardships are directed at a particular group because of their race, political beliefs, religion, etc., but is not applicable if economic oppression is used by an elite against the rest of the population.

When the question is raised about why asylum countries in general interpreted refugee asylum claims in a more restrictive manner, Jaeger answers that the explanation is not the large numbers: relative to wealth and population, the three to four million refugees concen- trated in the Northern Hemisphere in the 1920 s could be viewed as proportionately larger. Instead, Jaeger suggests, it is a combination of objective factors - unemployment, lack of arable land, ethnic incompatibilities, etc. - which make local and regional solutions more difficult. When these are combined with subjective factors such as the fear of escalating influxes because of a widespread collapse of a norm of peacable coexistence and what Jaeger dubs, "psychohistorical fatigue" (which may mean the same thing as the hip word of last year in refugee circles compassion fatigue) the refugee situation reaches a crisis point.

Corresponding to the alleged restriction in the application of the refugee definition, is the decline in the use of repatriation as a solution in Africa, the continent where the definition of a refugee is broadest. Although Joseph Cerquone documents successful cases of repatriation - 250,000 returned to Zimbabwe after the defeat of the white-dominated regime in Rhodesia, and 150,000 returned from Cameroon to Chad - political circumstances combined with economic assistance seem to be complementary components of successful repatriation efforts. The combination is the exception rather than the rule. The international community can only significantly influence the latter. And the alternative to repatriation, i.e. self-sufficiency, is more experimental than widespread. The limited influence on repatriation and the limited application of selfsufficiency suggest that the alternatives to resettlement are suffering as well.

My article on the Palestinians, while acknowledging a connection, differentiates the refugee question from the issue of self-determination. The old welfare definition in terms of need is replaced by the broadest political definition of Palestinian refugees, a definition which goes beyond that of the UNHCR to include in-homeland, uprooted individuals who lack a state of their own which guarantees their protection in the fullest sense of the term. After a long review of numbers and the situation of

Continued on $p .18$ 


\section{Survey}

Continued from p. 17

the 600,000 Palestinian refugees (according to this broadest political definition), the article focuses on the serious plight of the Palestinian refugees in Lebanon who lack even an international agency with an ostensible responsibility for their protection.

Abraham Karlikow reviews the background to the exodus of $121 / 2 \%$ of the Soviet Jews and the increasing restrictions on exit visas during the last few years since the peak exodus in 1979 of over 50,000 . Karlikow suggests, rather than argues, that the easing of restrictions on the exit of Soviet Jews is a direct correlative of improved U.S.-USSR relations. The peaks of 1972 and 1973 corresponded to an ease in trade between the U.S. and the USSR, while the decline could be correlated with restrictions to that trade, particularly the Congressional Amendment to the Trade Act on December 13, 1974 which limited credit to the USSR to a mere $\$ 300$ million

The peaks of 1978 and 1979 are correlated with another area of U.S.-USSR cooperation when SALT I was signed.

Other factors may have impacted on the shifts in policy - a shift from traditional Jews or Jews with religious or Zionist convictions to assimilated Jews from the heartland of Russia reacting to increasing discriminatory actions against Jewish access to higher education, and the increasing numbers of Soviet Jews opting to go to the U.S., Canada and Australia rather than Israel. But the central theme is the state of detente. The reaction of the West to Afghanistan, Poland and the arms buildup, capped by Reagan's rhetorical anti-Sovietism, can be correlated with the smallest number of visas since the sixties. Corresponding to the decline is an increased oppression of Jews in the USSR, indicated by mounting antisemitism.

Karlikow's article ends with a call for increasing international pressure. $\mathrm{He}$ argues that the USSR reveals its susceptibility to such pressure when it stages press conferences to counter anti-Soviet publicity on the issue. Unfortunately, the article itself seems to undermine its hortatory conclusion in its objective documentation that Soviet-Jewish exit visas are a direct trade-off with less restrictive policies to the Soviet Union.
There is no evidence to suggest that superego campaigns against the Soviet Union can be correlated with the easing of exit restrictions or internal discrimination and persecution of dissidents.

Paul Cullen documents the radical shift in Australian policy from one which centred on whites only to a record which gave Australia the highest per capita intake of Indochinese refugees from 1975 to 1982 . Unlike Canada, but like Europe, Australia inducts most of its refugees through migrant centres, with small interest-free loans available to the refugees when they move out of those centres. However, a small but increasing number have bypassed the migrant centres since October 1979, moving directly into the community with the support of voluntary groups. One regrets, as with many of the other articles, that the pieces are so cursory and descriptive and that more critical and probing analysis is not available.

This is certainly true of James Carlin's article on the Intergovernmental Committee for Migration which documents ICM's role and versatility in processing and transporting over two million refugees in its 32-year history. When we get to the articles concerned with American policy, we find we go beyond description to either a moral condemnation or defense of American refugee policy.

In his article on Central American refugees, Sid Mohn documents the tensions between State Department policy, which does not grant refugee status to those who flee regimes to whom the U.S. is providing military assistance, and U.S. religious and human rights agencies who have gone beyond the practice of simple criticism to action programs providing underground railways and religious sanctuaries to Salvadoran and Guatemalan refugees. They condemn the U.S. government as doubly guilty - first, in propping up military oppressive regimes which are the major source of the refugee exodus, and then in deporting the refugees to potential persecution or even death.

In this context, there is an excellent brief insert by Richard Feen on the ethical assumptions underlying actions on behalf of refugees. These ethical assumptions can be rooted in a foreign policy of "shared humanity" or the much more restrictive "ally responsiveness". The norms can be grounded in domestic collective values - the idea of the U.S. as a haven for the oppressed or, on the other hand, the obligation to maintain the integrity and security of the existing culture. The values can also be based on domestic individual premises - heroic altruism, minimal altruism (help as long as no great sacrifice is involved) and social Darwinism

Hamilton Fish, Jr., a Republican Representative from New York, writes an apologia which casts the U.S. in a heroic light - as the protector of the world's persecuted, buffetted, at present, by public pressure propelled by the "illegal migration" from Cuba and Haiti. Fish advocates strong measures to restrict "illegal migrants" to enable, as he sees it, the U.S. to provide refuge to the real victims of persecution. The rhetoric simply obfuscates the underlying issues.

Similarly, the 1982 Refugee Assistance Amendments, which require more ex-

\section{New Appointment}

Lloyd Jones, Longhouse Village, R.R. 13, Thunder Bay, Ontario, P7B 5E4, has been appointed refugee resettlement field officer for Canada for the Hong Kong Christian Service.

His duties are to co-ordinate the Canadian resettlement of refugees now in Hong Kong under private sponsorship.

Lloyd, a graduate of McMaster University, and the University of the Pacific, has been involved in resettlement of refugees, including minor unaccompanied sponsorships for the past four years. He and his wife Willa operate an International C.H.A. hostel in Thunder Bay.

Financial assistance is available for the sponsorship of Indochinese refugees from Hong Kong. If you are interested in sponsorships of Vietnamese refugees, be free to call Lloyd at 807-983-2042.

Lloyd Jones is also interested in the Central American refugee work. His church in Thunder Bay has assisted in finding sponsorships for 4 minor unaccompanied El Salvadorean and Guatemalan teenagers. 
change of information between voluntary agencies and welfare agencies, are lauded as a means to prevent the refugee from becoming dependant on welfare - a fixation unique to American refugee discourse. Because of the way in which it is presented, Fish's proposal is made to seem moderate. He uses as foils, the Huddleston Amendment, which proposes to integrate refugee and immigration totals, thereby ensuring that family reunification migrants would compete with refugees for a limited number of slots, and the Bumpers Amendment, which proposes to restrict total non-emergency emissions to 75,000 through a Congressional Veto. In the American context, it may indeed reflect a mind set convinced that alternatives to resettlement, particularly voluntary repatriation, should be pursued (in spite of the evidence in the same periodical of the limits to such efforts) to counteract the "pull factors" alleged to have acted as a major motor to refugee flows.

The first of the last two articles on Indochinese adaptation focuses on the premise of increased welfare dependency of the Indochinese, and seeks to explore whether the source of this dependency is in the program, in the opportunities available in the local community, or in the refugees themselves. Increasing labour force participation rates correlated with time of entry and the recent recession suggest the problem does not stem primarily from either the program or the refugees themselves but in the opportunities available to the refugees. This interpretation is supported by the high rate of employment and low wage entry-level positions and in the expanding employment sectors such as the electronic industry. When the situation of the refugees themselves is addressed, problems of welfare are correlated with language ability and the proportion of employed persons in the refugee household, since it would appear that self-sufficienty for many refugees usually requires the efforts of more than one wage-earner per family.

The final article by John Finck entitled, "Progress Towards Self-Sufficiency of the Indochinese" is really a celebration of the whole gamut of social adaptation strategies, of which economic selfsufficiency is but a part.

The statistical section requires a review of its own. The 1983 Survey is an improvement over 1982 in distinguishing 'refugees in need' from the number of refugees who have long been re-established in resettlement countries. This reduces the world total to $7,860,200$ refugees. Even then, problems of definition and reliability of information affect the credibility of the data.

The editor argues that "judicious decisions have been made in choosing sources and figures", but judicious is a weasel word. It can, on the one hand, mean carefully weighed judgements of all sources of data or, on the other hand, it can connote diplomatic pragmatics. For example, what definition is used for Palestinian refugees? Is it consistent with the definition involving other refugees? What are the sources? When the data in the country surveys directly conflict with the data provided in the articles published by World Refugee Survey itself, which figures are to be taken as the authoritative source? Don't the discrepancies publicized by the same journal in the same issue require at least an explanation?

A case in point is the 45,000 Ugandan refugees listed in Rwanda. This figure is consistent with the figures given in the article on the Banyarwanda, but the 69,900 listed from Rwanda in Uganda is consistent with the article only if 34,900 displaced citizens and long-term Banyarwanda residents of Uganda who joined the 35,000 in existing refugee camps in Uganda are also defined as refugees. Under even the broadest political definition of refugees (which I used in approaching the Palestinian issue), displaced citizens within a country are not refugees.

In contrast, when we consider the Palestinians, my published article shows 217,000 in the Gaza Strip while the Table shows 377,000 . The Table numbers 749,000 Palestinian refugees in Jordan in spite of the fact that these Palestinians were given citizenship long ago. The editor's preamble clearly states - "everyone would probably agree that the status ceases to be salient at some point...for example, refugee individuals who have obtained a permanent legal status in a nation." Further, the Table directly contradicts its stated basis - "to separate specifically refugees in need and those resettled or generally deemed to be settled or otherwise 'no longer in need'". Either one of these three criteria can be used to exclude individuals from the 'in need' category. Since the Palestinians in Jordan fill at least one and sometimes all three of these criteria, they should not be included in the list. And yet they are.

Statistical collections which are scissors and paste collages of conflicting criteria are virtually useless and add to the credibility gap. If World Refugee Survey is to publish a reliable reference guide to numbers, it will have to be consistent with its professed criteria, definitions and sources of data. Until then, I am afraid its 'judicious' handling of figures is more a matter of being unwilling to step on toes than a fair and considered assessment of the variety of sources and definitions of refugees.

H.A.

\section{The Canadian Foundation for Refugees}

The financial report for the year ended June 30,1983 was received. It showed current cash assets of $\$ 171,000$, a decrease of $\$ 18,000$ in cash to cover the excess of operating expenses over income. The income of $\$ 20,000$ was earned as interest on its cash. No monies were given to any refugee aid organization. Instead, over $\$ 38,000$ was spent $(\$ 20,000$ from income and $\$ 18,000$ from capital) as follows:

- over $\$ 16,000$ (almost $1 / 2$ ) for travel costs of the directors and staff
- over $\$ 9,000$ for professional services (presumably the community animateur)

- over $\$ 4,000$ for promotional media (presumably for publication of Let's Learn English)

\section{$\$ 7,000$ office expense $\$ 36,000$}

This budget does not include the up to $\$ 200,000$ it costs CEIC in office space, seconded officials, furnishings, telecommunications and other supplies. 


\section{REFUGE NEEDS YOUR HELP}

Since May 1981, Refuge has been providing information on Canadian and international refugee issues and concerns.

\section{Comments Received}

"reliable and relevant information"

"Pithy articles, backed by scholarly research"

"highly recommended reading"

We need to triple our subscriptions to survive and to prevent a large increase in subscription rates. Please help. It is easy:

1. Buy one gift subscription.

2. Ask two acquaintances to subscribe.

3. Send self-addressed envelopes and we will mail sample issues to your friends and associates.

4. Ask your local library to subscribe.

Refuge, is a non-profit, non-advertising periodical. We depend upon the support of subscribers.

\section{REFUGE is a non-profit, bi-monthly publication about refugees.}

SUBSCRIPTION RATES: (one year)

$\square \$ 10$ (U.S. or Canadian) ${ }^{\star} \quad$ Individual and non-profit organizations

$\square \$ 20$ (U.S. or Canadian) Libraries and institutions

*Please note: because of bank charges on foreign cheques, we are unable to discount U.S. funds.

Please enclose payment with your order.

Name Organization

Address

City Province or State

Country Postal Code

Phone Occupation

REFUGE, c/o Refugee Documentation Project, York University 4700 Keele Street, Downsview Ontario M3J 2R6 